\title{
ANALISIS KINERJA APOTEKER DALAM PELAYANAN FARMASI KLINIK DI PUSKESMAS KOTA BANJARMASIN
}

\author{
Karina Erlianti $^{1)}$, Hasniah ${ }^{1)}$, Lia Mardiana ${ }^{1)}$ \\ ${ }^{1}$ Fakultas Ilmu Farmasi Universitas Islam Kalimantan Muhammad Arsyad Al Banjari Banjarmasin \\ Email: karina.erlianti@gmail.com
}

\begin{abstract}
The performance of a pharmacist needs to be evaluated to improve the quality of pharmaceutical services, both in clinical pharmacy services and drug management. This study aims to provide an overview the performance of pharmacists at Public Health Center (PHC) of Banjarmasin in providing clinical pharmacy services. This study is descriptive study. Data were retrospectively retieved by document exploration and equipped with qualitative data through observation sheet and in-depth interview with key personel. Pharmacist performance and the influence of demographic characteristics to performance was analyzed descriptively. The number of respondents in this study were 5 pharmacists who practiced in five PHC of Banjarmasin that represented every sub-district in Banjarmasin City. The results of this study show us the performance of pharmacists in clinical pharmacy services at PHC in the era of the National Health Insurance was in a very high category in the aspect of using generic drugs, the average drug item in prescriptions and injection use in myalgia with $100 \%$ performance achievement. The high performance category is shown in the aspect of prescription assessment (performance achievement $86.62 \%$ ), delivery and provision of drug information (82.70\% achievement) and the use of antibiotics in non-specific diarrhea (performance achievement 75.44\%). The category of moderate performance is shown through aspects of patient counseling (performance achievement 70\%) and the use of antibiotics in non-pneumonia acute respiratory infection (performance achievement 67.61\%).
\end{abstract}

Keywords: Pharmacists, Performance, Clinical Pharmacy, Primary Healthcare Center

\section{PENDAHULUAN}

Pelayanan kefarmasian di puskesmas dilakukan secara terpadu dengan tujuan untuk mengidentifikasi, mencegah dan menyelesaikan masalah obat dan masalah yang berhubungan dengan kesehatan. Pelayanan kefarmasian di Puskesmas dilakukan dengan menerapkan Standar Pelayanan Kefarmasian di Puskesmas, yang merupakan tolak ukur dn pedoman penyelenggaraan pelayanan kefarmasian di Puskesmas oleh tenaga kefarmasian (Kemenkes RI, 2016). Penelitian ini bertujuan untuk memberikan gambaran kinerja apoteker di Puskesmas Kota Banjarmasin dalam melakukan pelayanan farmasi klinik.

Apoteker merupakan salah satu tenaga kesehatan yang berperan dalam penggunaan sediaan farmasi dan bahan medis habis pakai yang berkualitas di Puskesmas serta memberikan pelayanan kefarmasian serta mencegah, mengidentifikasi dan mengurangi masalah-masalah terkait obat dan peresepan. Apoteker harus dapat menampilkan profesionalismenya seperti yang ditetapkan pada Standar Komptensi Apoteker dan Standar Pelayanan Kefarmasian (Coombes et al., 2010). Kinerja seorang apoteker dalam melakukan pelayanan kefarmasian di Puskesmas perlu dianalisis untuk meningkatkan kualitas pelayanan kefarmasian baik dalam pelayanan farmasi klinik maupun pengelolaan sediaan farmasi dan bahan medis habis pakai (Kemenkes RI, 2016). Penelitian sebelumnya yang dilakukan oleh Satibi et al menyatakan bahwa kinerja Apoteker dalam melakukan pelayanan kefarmasian di Puskesmas sudah baik atau berada pada kategori tinggi (Satibi et al., 2018). Kinerja merupakan faktor multidisiplin yang dipengaruhi berbagai hal baik dari faktor individu maupun tempat kerja. Oleh karena itu pada penelitian ini dilakukan analsis faktor-faktor yang mungkin dapat berpengaruh terhadap kinerja apoteker yaitu usia, jenis kelamin, tingkat pendidikan, gaji dan lama berpraktek.

Pelayanan farmasi klinik adalah pelayanan kefarmasian yang langsung dan bertanggung jawab kepada pasien berkaitan dengan obat dan Bahan Medis Habis Pakai (BMHP) yang bertujuan untuk 
meningkatkan mutu dan memperluas cakupan pelayanan kefarmasian di Puskesmas, memastikan pasien mendapatkan pengobatan yang efektif, aman dan efisien, meningkatkan kepatuhan pasien dalam pengobatan serta melaksanakan kebijakan obat di Puskesmas dalam rangka meningkatkan penggunaan Obat secara rasional.

Kota Banjarmasin memiliki dua puluh enam puskesmas yang tersebar di lima kecamatan. di kota Banjarmasin, Puskesmas merupakan pilihan utama bagi masyarakat untuk berobat jalan dibandingkan dengan fasilitas kesehatan lainnya (Pemkot Banjarmasin, 2005). Dengan semakin meningkatnya kunjungan masyarakat ke Puskesmas maka Pelayanan Kesehatan di Puskesmas harus terus ditingkatkan termasuk Pelayanan Kefarmasian yang di lakukan oleh Apoteker. Salah satu cara yang dapat dilakukan untuk meningkatkan pelayanan kefarmasian oleh apoteker di Puskesmas adalah dengan mengetahui kinerja apoteker di Puskesmas dalam melakukan Pelayanan Farmasi Klinis.

\section{METODE PENELITIAN \\ Penetapan Populasi}

Populasi target dalam penelitian ini adalah Apoteker yang melakukan pelayanan farmasi klinik di Puskesmas Kota Banjarmasin Kalimantan Selatan. Apoteker yang menjadi responden dalam penelitian kemudian ditentukan berdasarkan Puskesmas tempat berpraktek yang mewakili setiap kecamatan yang ada di Kota Banjarmasin yaitu Puskesmas Banjarmasin Indah pada Kecamatan Banjarmasin Barat, Puskesmas Alalak Tengah pada Kecamatan Banjarmasin Utara, Puskesmas Cempaka Putih pada Kecamatan Banjarmasin Timur, Puskesmas Teluk Dalam pada Kecamatan Banjarmasin Tengah dan Puskesmas Pekauman pada Kecamatan Banjarmasin Selatan.

\section{Kriteria Inklusi dan Eksklusi}

Kriteria inklusi dalam penelitian ini adalah Apoteker yang melakukan pelayanan farmasi klinik di Puskesmas Kota Banjarmasin. Kriteria eksklusi dalam penelitian ini adalah apoteker dengan data pekerjaan kefarmasian pada pelayanan farmasi klinik yang tidak dapat diakses.

\section{Pengumpulan dan Seleksi Data}

Penentuan sampel pada penelitian ini dilakukan dengan purposive sampling, yang merupakan teknik penentuan sampel dengan pertimbangan tertentu. Puskesmas yang digunakan pada penelitian ini adalah
5 (lima) Puskesmas yang mewakili setiap kecamatan yang ada di Kota Banjarmasin dan didasarkan atas jumlah kunjungan perhari yaitu tertinggi, sedang dan terendah.

\section{Sumber Data dan Instrumen Penelitian}

Sumber data yang digunakan dalam penelitian ini adalah sumber data primer yaitu hasil observasi dengan daftar tilik dan wawancara mendalam mengenai pelayanan farmasi klinik. Serta menggunakan sumber data sekunder yaitu Laporan Penggunaan Obat Rasional dan Laporan Penggunaan Obat Generik.

Instrumen penelitian yang digunakan yaitu daftar tilik yang disusun oleh Direktur Jenderal Bina Kefarmasian dan Alat Kesehatan tentang Pelayanan Farmasi Klinis dan pedoman wawancara mendalam.

\section{Analisis dan Pengolahan Data}

Penilaian kinerja apoteker di analisis berdasarkan indikator pada setiap Puskesmas berdasarkan observasi dengan daftar tilik. Setiap indikator pada aspek pelayanan farmasi klinik tersebut kemudian dihitung dan didapatkan nilai realisasi. Nilai realisasi kemudian diubah menjadi persentase capaian kinerja apoteker. Persentase capaian dari masing-masing indikator kemudian dikategorikan menjadi kategori capaian kinerja seperti yang tertera pada Tabel 1 .

Tabel 1. Kategori Pencapaian Sasaran

\begin{tabular}{ccc}
\hline Urutan & \%Capaian & Kategori \\
\hline I & $>90 \%$ & Sangat Berhasil \\
\hline II & $75 \%-90 \%$ & Berhasil \\
\hline III & $65 \%-75 \%$ & Cukup Berhasil \\
\hline IV & $50 \%-65 \%$ & Kurang Berhasil \\
\hline V & $<50 \%$ & Tidak Berhasil \\
\hline
\end{tabular}

Analisis faktor yang mempengaruhi kinerja apoteker di Puskesmas Kota Banjarmasin dianalisis secara deskriptif berdasarkan data yang diperoleh dari hasil analisis kinerja apoteker berdasarkan indikator pelayanan farmasi klinik serta hasil wawancara mendalam. Hasil analisis disajikan dalam bentuk narasi disertai penjelasan mengenai faktor yang mempengaruhi kinerja Apoteker di Puskesmas kota Banjarmasin.

\section{HASIL DAN PEMBAHASAN}

Penelitian ini melibatkan responden sebanyak 5 (lima) responden yaitu Penelitian ini melibatkan responden sebanyak 5 (lima) responden yaitu Apoteker 
yang melakukan pelayanan kefarmasian di Puskesmas Kota Banjarmasin. Penelitian ini dilakukan pada 5 (lima) puskesmas di Kota Banjarmasin. Puskesmas yang dipilih sebagai lokasi penelitian mewakili setiap kecamatan di Kota Banjarmasin dan didasarkan pada kunjungan pasien perhari ke puskesmas. Puskesmas yang dipilih secara purposive sampling sebagai lokasi pada penelitian ini yaitu puskesmas yang tertera pada Tabel 2.

Tabel 2. Puskesmas Lokasi Penelitian

\begin{tabular}{llc}
\hline Nama Puskesmas & \multicolumn{1}{c}{ Kecamatan } & $\begin{array}{c}\text { Rata-rata } \\
\text { Kunjungan } \\
\text { Pasien/Hari }\end{array}$ \\
\hline $\begin{array}{l}\text { Banjarmasin } \\
\text { Indah }\end{array}$ & Banjarmasin Barat & 52 \\
\hline Alalak Tengah & Banjarmasin Utara & 54 \\
\hline Teluk Dalam & Banjarmasin Tengah & 71 \\
\hline Cempaka Putih & Banjarmasin Timur & 79 \\
\hline Pekauman & Banjarmasin Selatan & 180 \\
\hline
\end{tabular}

\section{Karakteristik Responden}

Responden yang mengikuti penelitian ini merupakan apoteker yang bekerja di lima (5) puskesmas kota Banjarmasin yang mewakili setiap kecamatan yang terdapat di Kota Banjarmasin dan bersedia mengikuti penelitian ini. Bersedianya responden dalam mengikuti penelitian ini ditandai dengan kesediaannya untuk menandatangani informed consent setelah menerima penjelasan dari peneliti secara lengkap terkait dengan penelitian yang dilakukan. Karakteristik yang diidentifikasi dalam penelitian ini meliputi jenis kelamin, usia, pendidikan, lama bekerja, status kepegawaian dan Penghasilan. Variabel usia dibagi menjadi $<35$ tahun dan $\geq 35$, serta variabel lama masa kerja dibagi menjadi $<8$ tahun dan $\geq 8$ tahun yang didasarkan atas rata-rata dari keseluruhan usia dan masa kerja sebagai cut of point. Sebaran karakteristik responden secara rinci dapat dilihat pada tabel 3.

Tabel 3. Karakteristik Responden

\begin{tabular}{cccc}
\hline \multirow{2}{*}{ Variabel } & Kategori & \multicolumn{2}{c}{$\begin{array}{c}\text { Apoteker } \\
(\mathbf{N}=5)\end{array}$} \\
\cline { 2 - 4 } & & $\mathrm{N}$ & $\%$ \\
\hline Jenis & Perempuan & 2 & 40 \\
\cline { 2 - 4 } Kelamin & Laki-laki & 3 & 60 \\
\hline Usia & $<35$ Tahun & 2 & 40 \\
& $\geq 35$ Tahun & 3 & 60 \\
\hline Pendidikan & Apoteker & 5 & 100 \\
\hline Lama & $<8$ Tahun & 3 & 60 \\
Bekerja & $\geq 8$ Tahun & 2 & 40 \\
\hline Penghasilan & $<\mathrm{Rp} 3.600 .000,00$ & 1 & 20 \\
& $\geq \mathrm{Rp} 3.600 .000,00$ & 4 & 80 \\
\hline
\end{tabular}

Kinerja Apoteker Dalam Pelayanan Farmasi Klinis

Pelayanan farmasi klinik adalah bagian dari pelayanan kefarmasian yang langsung dan bertanggung jawab kepada pasien. Pelayanan farmasi klinik bertujuan untuk meningkatkan mutu dan memperluas cakupan pelayanan kefarmasian di Puskesmas, memberikan pelayanan kefarmasian yang dapat menjamin efektivitas, keamanan dan efisiensi obat, meningkatkan kerjasama dengan profesi kesehatan lain dan kepatuhan pasien yang terkait dalam pelayanan kefarmasian serta, melaksanakan kebijakan obat di Puskesmas dalam rangka meningkatkan penggunaan Obat secara rasional. Capaian kinerja apoteker dalam melakukan pelayanan farmasi klinik pada penelitian ini di analisis melalui aspek pengkajian dan pelayanan resep, konseling serta evaluasi penggunaan obat.

\section{Pengkajian dan Pelayanan Resep}

Pengkajian resep merupakan kegiatan yang dimulai dari seleksi persyaratan administrasi, farmasetik dan klinis sedangkan pelayanan resep merupakan kegiatan yang terdiri dari penyerahan (dispensing) dan Pemberian Informasi Obat yang bertujuan agar pasien memperoleh Obat sesuai dengan kebutuhan pengobatan dan memahami tujuan pengobatan serta mematuhi instruksi pengobatan yang telah ditentukan (Kemenkes RI, 2016). Kinerja apoteker dalam melakukan pengkajian dan pelayanan resep dalam penelitian ini dilakukan dengan obeservasi langsung di lapangan dengan menggunakan daftar tilik. Observasi terhadap pengkajian resep yang dilakukan oleh apoteker diamati dengan daftar tilik pengkajian resep dengan hasil seperti yang tercantum pada tabel 4 .

Tabel 4. Hasil Observasi Pengkajian Resep

\begin{tabular}{ccccc}
$\begin{array}{c}\text { Target } \\
\text { Skor }\end{array}$ & Puskesmas & $\begin{array}{c}\text { Skor Capaian } \\
(\boldsymbol{\%})\end{array}$ & $\begin{array}{c}\text { Kategori } \\
\text { Capaian }\end{array}$ \\
\hline $\mathbf{1 0}$ & Alalak Tengah & 7,50 & 75,00 & Sedang \\
\cline { 2 - 5 } & $\begin{array}{c}\text { Banjarmasin } \\
\text { Indah }\end{array}$ & 8,33 & 83,30 & Tinggi \\
& Cempaka Putih & 9,16 & 91,60 & Sangat Tinggi \\
\cline { 2 - 5 } & Pekauman & 9,16 & 91,60 & Sangat Tinggi \\
\cline { 2 - 5 } & Teluk Dalam & 9,16 & 91,60 & Sangat Tinggi \\
\hline & Rata-rata \pm SD & 8,66 & 86,62 & Tinggi \\
\hline
\end{tabular}

Proses ini merupakan tahapan yang penting untuk memastikan kebenaran resep yang akan dilayani karena dapat mencegah terjadinya kesalahan obat (Hartanto, 2017). Penelitian ini menunjukkan bahwa 
skor yang didapatkan apoteker dalam melakukan pengkajian resep adalah sebesar 8,66 dan apabila diubah kedalam persentase capaian maka capaian kinerja apoteker pada indikator ini adalah sebesar $86,62 \%$ atau termasuk dalam kategori tinggi.

Penelitian ini menunjukkan capaian kinerja apoteker pada indikator ini telah termasuk kedalam kategori tinggi, namun masih terdapat beberapa kegiatan yang belum dilakukan oleh Apoteker di Puskesmas Kota Banjarmasin dalam pengkajian resep seperti memberikan nomor urut pada resep, pemeriksaan alergi, interaksi dan efek samping obat serta, pemeriksaan kontra indikasi. Di Puskesmas Kota Banjarmasin, meskipun resep tidak diberikan nomor urut pengerjaan dan pelayanan resep tetap dilakukan sesuai dengan urutan masuknya.

Apoteker di Puskesmas Kota Banjarmasin menyatakan bahwa pemberian nomor urut pernah dilakukan namun dirasa tidak efektif sehingga nomor urut tidak digunakan lagi namun apoteker tetap menjamin bahwa resep tetap dilayani sesuai dengan urutanya. Pemeriksaan alergi, interaksi, efek samping dan kontra indikasi jarang dilakukan. Pemeriksaan alergi hanya dilakukan pada pasien yang pertama kali berobat di Puskesmas terkait, sedangkan efek samping hanya di amati pada obat-obat tertentu yang sering menimbulkan reaksi efek samping pada kebanyakan pasien misalnya captopril yang dapat menyebabkan batuk kering. Interaksi obat hanya dilihat sekilas atau tidak terlalu diperhatikan karena apoteker di Puskesmas Kota Banjarmasin menganggap bahwa obat yang diresepkan dokter di Puskesmas tersebut merupakan obat yang hampir sama setiap harinya. Penelitian sebelumnya menyatakan bahwa Pemeriksaan alergi, interaksi, efek samping dan kontra indikasi jarang dilakukan dikarenakan adanya keterbatasan sumber daya manusia dan waktu yang lebih banyak, meskipun sebenarnya pertimbangan-pertimbangan tersebut merupakan hal yang penting dilakukan untuk mencegah terjadinya medication error (Latifah, Pribadi and Yuliastuti, 2016).

Kinerja Apoteker dalam melakukan pelayanan resep diobservasi langsung dengan menggunakan daftar tilik penyerahan dan pemberian informasi obat kepada pasien saat melakukan penyerahan obat. Hasil observasi terhadap kinerja apoteker dalam penyerahan dan pemberian informasi obat dapat dilihat pada tabel 5 . Hasil dari penelitian ini menunjukkan kinerja apoteker dalam penyerahan dan pemberian informasi obat saat penyerahan memperoleh skor sebesar 8,28 atau sebesar $82,70 \%$ (kategori tinggi) setelah diubah kedalam persentase capaian. Penelitian ini menunjukkan terdapat beberapa kegiatan atau standar yang belum dipenuhi apoteker dalam aspek ini. Beberapa kegiatan yang belum dilakukan apoteker diantaranya adalah memberikan informasi efek samping obat kepada pasien, memberikan informasi cara penyimpanan obat sesuai aturan serta memastikan bahwa pasien telah mengerti cara pemakaian obat. Tidak semua apoteker di Puskesmas Kota Banjarmasin memberikan informasi mengenai efek samping obat, kebanyakan apoteker hanya menyampaikan efek samping obat yang sering terjadi misalnya obat yang memiliki efek samping mengiritasi lambung. Informasi mengenai penyimpanan hampir semua apoteker di puskesmas tidak menyampaikan nya kepada pasien, informasi penyimpanan hanya dilakukan pada obat-obat tertentu yang harus disimpan pada kondisi khusus misalnya suppositoria serta tidak semua apoteker memastikan kembali bahwa pasien telah mengerti cara pakai obat yang telah disampaikan. Pemberian informasi yang benar, objektif dan lengkap akan mendukung pemberian pelayanan kesehatan yang terbaik kepada masyarakat sehingga kemanfaatan dan keamanan penggunaan obat dapat meningkat (Wibowo et al., 2016). Pernyataan tersebut juga didukung oleh penelitian sebelumnya yang menyatakan bahwa informasi yang lengkap dan jelas sangat diperlukan untuk disampaikan kepada pasien, karena pemberian informasi yang jelas dan lengkap dapat meminimalisasi terjadinya medication error dan meningkatkan efikasi obat yang digunakan oleh pasien (Latifah, Pribadi and Yuliastuti, 2016).

Tabel 5. Hasil Observasi Penyerahan dan Pemberian Informasi Obat

\begin{tabular}{ccccc}
\hline $\begin{array}{c}\text { Target } \\
\text { Skor }\end{array}$ & Puskesmas & Skor & $\begin{array}{c}\text { Capaian } \\
(\%)\end{array}$ & $\begin{array}{c}\text { Kategori } \\
\text { Capaian }\end{array}$ \\
\hline $\mathbf{1 0}$ & $\begin{array}{c}\text { Alalak } \\
\text { Tengah }\end{array}$ & 7,15 & 71,50 & Sedang \\
\cline { 2 - 5 } & $\begin{array}{c}\text { Banjarmasi } \\
\text { n Indah }\end{array}$ & 8,50 & 85,00 & Tinggi \\
\cline { 2 - 4 } & $\begin{array}{c}\text { Cempaka } \\
\text { Putih }\end{array}$ & 9,28 & 92,80 & Sangat Tinggi \\
\cline { 2 - 4 } & & & \\
\hline $\begin{array}{c}\text { Pekauman } \\
\text { Teluk } \\
\text { Dalam }\end{array}$ & 9,28 & 92,80 & Sangat Tinggi \\
\hline $\begin{array}{c}\text { Rata- } \\
\text { rata } \pm \text { SD }\end{array}$ & 8,28 & 81,40 & Sedang \\
\hline
\end{tabular}




\section{Konseling}

Konseling adalah proses yang dilakukan untuk mengidentifikasi dan penyelesaian masalah pasien yang berkaitan dengan penggunaan obat. Konseling bertujuan untuk memberikan pemahaman yang benar mengenai obat kepada pasien maupun keluarga pasien terkait dengan tujuan dan jadwal pengobatan, cara dan lama penggunaan obat, efek samping, tanda-tanda toksisitas serta cara penyimpanan dan penggunaan obat (Kemenkes RI, 2016).

Capaian kinerja apoteker dalam melakukan konseling di Puskesmas Kota Banjarmasin pada penelitian ini diobservasi langsung dengan menggunakan daftar tilik konseling. Hasil observasi menunjukkan kinerja apoteker dalam melakukan konseling ditunjukan pada tabel 6 .

Tabel 6. Hasil Observasi Konseling

\begin{tabular}{ccccc}
\hline $\begin{array}{c}\text { Target } \\
\text { Skor }\end{array}$ & Puskesmas & Skor & $\begin{array}{c}\text { Capaian } \\
(\mathbf{\%})\end{array}$ & $\begin{array}{c}\text { Kategori } \\
\text { Capaian }\end{array}$ \\
\hline $\mathbf{1 0}$ & Alalak Tengah & 7,50 & 75 & Sedang \\
\cline { 2 - 5 } & $\begin{array}{c}\text { Banjarmasin } \\
\text { Indah }\end{array}$ & 7,50 & 75 & Sedang \\
\cline { 2 - 5 } & $\begin{array}{c}\text { Cempaka } \\
\text { Putih }\end{array}$ & 6,25 & 62,5 & Rendah \\
& & & \\
\hline Pekauman & 7,50 & 75 & Sedang \\
\cline { 2 - 4 } & Teluk Dalam & 6,25 & 62,5 & Rendah \\
\hline & Rata-rata \pm SD & 7,00 & 70,00 & Sedang \\
\hline
\end{tabular}

Hasil observasi pada penelitian ini menunjukkan konseling yang dilakukan oleh apoteker di Puskesmas Kota Banjarmasin memiliki skor sebesar 7,00 dengan persentase capaian kinerja sebesar $70,00 \%$ atau termasuk dalam kategori tinggi. Hasil penelitian ini menunjukkan masih terdapat kegiatan yang belum dilakukan apoteker pada indikator konseling ini. Idealnya konseling harus dilakukan dengan baik dan benar, karena konseling memiliki peran yang sangat penting tidak hanya dapat meningkatkan kepatuhan pasien tetapi juga dapat mengurangi komplikasi penyakit yang dapat terjadi sebagai akibat dari ketidaktaatan terhadap pengobatan (Palaian, Prabhu and Shankar, 2006). Konseling yang diberikan kepada pasien dapat meningkatkan kepatuhan pengobatan pasien dan kepuasan terhadap kepuasan pengobatan sehingga secara meningkatkan outcome klnis pada pengobatan pasien (Sanii et al., 2016).

Kegiatan atau standar yang masih belum dilakukan pada aspek konseling diantaranya adalah menanyakan hal-hal mengenai obat yang dikatakan oleh dokter kepada pasien dengan metode pertanyaan terbuka, melakukan konseling pada ruangan khusus konseling dan konseling yang dilakukan terdokumentasi dengan baik. Di Puskesmas Kota Banjarmasin apoteker tidak melakukan konseling di ruangan khusus karena semua Puskesmas di Kota Banjarmasin belum memiliki fasilitas ruang konseling. Penelitian yang dilakukan Ejeta menunjukkan bahwa tidak tersedianya ruangan konseling pada fasilitas kefarmasian merupakan salah satu penyebab tidak optimal nya pelaksanaan konseling oleh Apoteker kepada pasien (Ejeta et al., 2021). Dinas Kesehatan Kota Banjarmasin tidak mengharuskan apoteker untuk mendokumentasikan konseling yang dilakukan dan apoteker di Puskesmas Kota Banjarmasin mengaku belum tahu bagaimana konseling harus didokumentasikan, misalnya terkait dengan format atau bentuk lembar dokumentasinya. Apoteker di Puskesmas Kota Banjarmasin menyatakan bahwa meskipun konseling telah dilakukan kepada beberapa pasien sebenarnya terdapat beberapa kendala dalam melakukan konseling seperti keterbatasan yang telah disebutkan sebelumnya yaitu keterbatasan fasilitas (ruangan konseling) serta keterbatasan tenaga, dimana setiap Puskesmas di Kota Banjarmasin hanya memiliki satu apoteker yang juga melakukan pelayanan resep dan tanggung jawab administratif lainnya. Hal ini juga sejalan dengan hasil wawancara yang dilakukan bahwa apoteker di Puskesmas lebih disibukan dengan tanggung jawab administratif dan tugas pelayanan kefarmasian lainnya (Narasi 1).

"Konseling memang jarang dilakukan, dikarenakan keterbatasan waktu dan tenaga yang ada di puskesmas. Beban kerja Apoteker di Puskesmas sudah sangat berat pada adminstrasi, pengelolaan obat dan pelayanan resep"

Penelitian yang dilakukan oleh Rajiah dkk. (2016) juga menyatakan hal yang serupa, yaitu apoteker berpersepsi positif dalam melakukan konseling kepada pasien namun dalam melakukan konseling tersebut apoteker merasa masih memiliki beberapa kendala seperti waktu yang tidak mencukupi untuk melakukan konseling diantara tanggung jawab lainnya, jumlah apoteker yang tidak mencukupi di fasilitas kesehatan, kurang nya rasa percaya diri apoteker untuk melakukan konseling serta adanya penolakan dari pasien ketika ditawarkan untuk diberikan konseling (Rajiah et al., 2016). 


\section{Evaluasi Penggunaan Obat}

Evaluasi penggunaan obat adalah kegiatan yang dilakukan untuk mengevaluasi penggunaan obat secara terstruktur dan berkesinambungan untuk menjamin obat yang digunakan sesuai indikasi, efektif, aman dan terjangkau (Kemenkes RI, 2016). Kinerja apoteker pada evaluasi penggunaan obat dalam penelitian ini dilihat dari indikator peresepan yang terdiri dari persentase penggunaan obat generik, persentase penggunaan antibiotik diare non spesifik dan ISPA non pneumonia serta persentase penggunaan injeksi untuk myalgia dan rata- rata item obat dalam resep. Indikator peresepan merupakan indikator yang digunakan untuk mengukur capaian keberhasilan penggunaan obat yang rasional dalam pelayanan kesehatan (Kemenkes RI, 2011). Pengobatan yang tidak rasional dapat berupa peresepan obat tanpa indikasi yang jelas, penentuan dosis, cara, dan lama pemberian yang keliru, serta peresepan obat yang mahal merupakan. Penggunaan suatu obat dikatakan tidak rasional jika kemungkinan dampak negatif yang diterima oleh pasien lebih besar dibanding manfaatnya. Dampak negatif tersebut dapat berupa dampak klinik misalnya terjadinya efek samping dan resistensi kuman dan dampak ekonomi atau biaya tidak terjangkau yang disebabkan ketidak rasionalan penggunaan obat. Data-data indikator peresepan dalam penelitian ini didapatkan melalui penelusuran dokumen di Puskesmas, yaitu meliputi:

\section{a) Persentase Penggunaan Obat Generik}

Obat generik merupakan obat dengan nama resmi International Non Propietary Names (INN) yang ditetapkan dalam Farmakope Indonesia atau buku standar lainnya untuk zat berkhasiat yang dikandungnya (Kemenkes RI, 2010). Dalam Peraturan Menteri Kesehatan Republik Indonesia tahun 2010 tentang Kewajiban Menggunakan Obat Generik di Fasilitas Pelayanan Kesehatan Milik Pemerintah dinyatakan bahawa Dinas Kesehatan Provinsi/Kabupaten/Kota wajib membuat perencanaan, pengadaan, penyimpanan, penyediaan, pengelolaan dan pendistribusian obat kepada puskesmas dan pelayanan kesehatan lainnya (Kemenkes RI, 2010). Target standar persentase penggunaan obat generik di Puskesmas pada tahun 2016 adalah sebesar 90\% (Kemenkes RI, 2015). Hasil dari penelitian ini ditunjukan pada Tabel 7.
Tabel 7. Persentase Penggunaan Obat Generik

\begin{tabular}{ccccc}
\hline $\begin{array}{c}\text { Target } \\
\text { Skor }\end{array}$ & Puskesmas & $\begin{array}{c}\text { Realisasi } \\
(\mathbf{1 0 \%})\end{array}$ & $\begin{array}{c}\text { Capaian } \\
\mathbf{( \% )}\end{array}$ & $\begin{array}{c}\text { Kategori } \\
\text { Capaian }\end{array}$ \\
\hline $\mathbf{9 0 \%}$ & $\begin{array}{c}\text { Alalak } \\
\text { Tengah }\end{array}$ & 84 & 93,33 & Sangat Tinggi \\
\cline { 2 - 5 } & $\begin{array}{c}\text { Banjarmasin } \\
\text { Indah }\end{array}$ & 98 & 100 & Sangat Tinggi \\
\cline { 2 - 5 } & $\begin{array}{c}\text { Cempaka } \\
\text { Putih }\end{array}$ & 99 & 100 & Sangat Tinggi \\
& $\begin{array}{c}\text { Pekauman } \\
\text { Teluk }\end{array}$ & 97 & 100 & Sangat Tinggi \\
\hline & 92 & 100 & Sangat Tinggi \\
\hline Dalam & Rata-rata & 94 & 100 & Sangat Tinggi \\
\hline
\end{tabular}

Penggunaan obat generik di Puskesmas Kota Banjarmasin telah sesuai dengan standar dengan persentase realisasi adalah sebesar 94\%, dengan capaian kinerja termasuk dalam kategori sangat tinggi (100\%). Realisasi penggunaan obat generik di Puskesmas Kota Banjarmasin adalah sebesar $94 \%$. Penelitian lain nya yang dilakukan oleh Handayani dkk. (2009) juga menunjukkan bahwa penggunaan obat generik di puskesmas sudah baik dengan ratarata sebesar 98,82\% (Handayani, $\mathrm{R}$ et al., 2009). Penelitian lainnya menunjukkan penggunaan obat generik di Puskesmas Kota Pariaman adalah sebesar 97,27\% atau dapat dikatakan juga telah memenuhi standar yang ditetapkan (Chaira, Zaini and Augia, 2016). Tercapainya standar ini didukung dengan pengadaan obat di Puskesmas yang harus dilakukan sesuai dengan Formularium Nasional yang berisi daftar obat dengan nama generik atau senyawa kimianya yang menjadi acuan dalam pemberian terapi kepada pasien (Tanner, Ranti and Lolo, 2015). Obat-obat non generik yang diresepkan di Puskesmas Kota Banjarmasin merupakan obat-obat kombinasi yang tidak ada sediaan generiknya serta obat-obat yang sediaan generiknya tidak tersedia atau kosong didistributor. Terkadang untuk menghindari kekosongan, apoteker mengganti obat generik yang kosong didistributor dengan obat branded yang memiliki khasiat sama. Penelitian lain yang dilakukan Tanner dkk. (2015) menerangkan bahwa alasan peresepan obat non generik oleh dokter difasilitas kesehatan adalah beberapa obat kombinasi akan menjadi tidak praktis dan menyulitkan pasien apabila dituliskan dengan nama generik, misalnya obat kombinasi dengan merk dagang Neurodex® tablet akan lebih praktis dan memudahkan pasien apabila diresepkan dan diberikan dengan merk 
dagang tersebut dibandingkan harus memberikan satu persatu kandungan zat aktif dari obat tersebut yaitu Vitamin B1, B6 dan B12, selain itu alasan lainnya adalah faktor pasien yang meminta untuk tidak diresepkan obat generik karena pengetahuan pasien yang masih kurang akan obat generic (Tanner, Ranti and Lolo, 2015). Oleh karena itu untuk meningkatkan persentase penggunaan obat generik di puskesmas diperlukan peran apoteker untuk melakukan pengadaan obat-obat yang sesuai dengan Fornas, melakukan komunikasi kepada penulis resep untuk senantiasa meresepkan obat generik serta memberikan pengetahuan dan pemahaman kepada masyarakat mengenai obat generik.

b) Rata-rata Item Obat Dalam Resep

Rata-rata jumlah item obat dalam resep adalah indikator yang digunakan untuk mengukur derajat polifarmasi. Polifarmasi merupakan penggunaan banyak obat secara bersamaan yang melebihi kebutuhan pengobatan pasien secara klinis (Holmes, 2012). Polifarmasi farmasi dapat menyebabkan efek negatif dari penggunaan suatu obat seperti reaksi efek samping dan interaksi obat (Kim et al., 2014). Ratarata jumlah item obat dalam resep di Puskesmas Kota Banjarmasin yaitu seperti yang tercantum pada Tabel 8.

Tabel 8. Rata-rata Item Obat Dalam Resep

\begin{tabular}{ccccc}
$\begin{array}{c}\text { Target } \\
\text { Skor }\end{array}$ & Puskesmas & $\begin{array}{c}\text { Realisasi } \\
(\mathbf{1 0 0 \% )}\end{array}$ & $\begin{array}{c}\text { Capaian } \\
\mathbf{( \% )}\end{array}$ & $\begin{array}{c}\text { Kategori } \\
\text { Capaian }\end{array}$ \\
\hline$\leq 3$ & $\begin{array}{c}\text { Alalak } \\
\text { Tengah }\end{array}$ & 3 & 100 & Sangat Tinggi \\
\cline { 2 - 5 } & $\begin{array}{c}\text { Banjarmasin } \\
\text { Indah }\end{array}$ & 3 & 100 & Sangat Tinggi \\
& $\begin{array}{c}\text { Cempaka } \\
\text { Putih }\end{array}$ & 2,58 & 100 & Sangat Tinggi \\
& $\begin{array}{c}\text { Pekauman } \\
\text { Pekalam }\end{array}$ & 3 & 100 & Sangat Tinggi \\
\hline Teluk Dalam & 100 & Sangat Tinggi \\
\hline Rata-rata & 2,92 & 100 & Sangat Tinggi \\
\hline & & & \\
\hline
\end{tabular}

Hasil penelitian ini menunjukkan kinerja apoteker di Puskesmas Kota Banjarmasin pada indikator ini adalah sangat tinggi dengan capaian sebesar $100 \%$. Rata-rata jumlah item obat dalam resep di Puskesmas Kota Banjarmasin telah memenuhi standar yang ditetapkan yaitu sebesar 2,92 item obat perlembar resep. Rata-rata jumlah item obat dalam resep pada masing-masing Puskesmas Kota Banjarmasin telah memenuhi standar yang ditetapkan atau tidak ada puskesmas Kota Banjarmasin yang memiliki rata-rata jumlah obat dalam resep lebih dari 3 (tiga).
Penelitian lainnya yang dilakukan pada tahun 2007 menunjukkan bahwa rata-rata jumlah item obat dalam resep di fasilitas kesehatan di Kota Bandung, Surabaya dan Makassar adalah sebesar 2,66 (Yuniar and Handayani, 2007). Penelitian yang dilakukan oleh WHO pada tahun 1990-1993 dalam Quick (2012), menggambarkan bahwa rata-rata item obat yang diresepkan di Indonesia berjumlah lebih dari 3 obat perlembar resep. Dari tiga penelitian tersebut dapat dilihat bahwa pada indikator ini fasilitas kesehatan di Indonesia terus mengalami perbaikan (Quick et al., 2012).

Menurut Yuniar dkk. (2007), tingginya rata-rata jumlah obat dalam resep dapat disebabkan oleh beberapa hal yaitu terjadi kekurangan obat-obat yang tepat secara terapetik, penulis resep kurang mendapat training terapetik atau peralatan diagnostik yang layak, penulis resep berfokus untuk menghilangkan gejala bukan pada diagnosis, pengobatan yang diberikan tanpa adanya pengujian klinis terhadap kondisi pasien, adanya permintaan pasien untuk diberikan obat-obat tambahan tertentu serta adanya insentif finansial yang mendukung terjadinya polifarmasi (Yuniar and Handayani, 2007). Polifarmasi dapat mengindikasikan bahwa obat-obat yang diterima oleh pasien merupakan obat yang tidak tepat, manfaatnya belum terbukti secara klinis, memiliki kemungkinan terjadinya interaksi obat dan akan mengakibatkan menurunnya kepatuhan pasien dalam konsumsi obat karena jumlah obat yang terlalu banyak (Duerden and Rupert, 2014)

c. Persentase Penggunaan Antibiotiok Pada Diare Non Spesifik dan ISPA Non Pneumonia

Antibiotik adalah senyawa yang berfungsi untuk membunuh atau menekan pertumbuhan bakteri. Antibiotik harus digunakan secara tepat dan rasional karena penggunaan antibiotik yang tidak tepat dapat menimbulkan kerugian baik secara klinis maupun finansial. Penggunaan antibiotik yang tidak tepat dapat menyebabkan terjadinya reaksi efeksamping, mengganggu sistem imunitas dan menyebabkan bakteri-bakteri menjadi resistensi terhadap antibiotik (Rifa'i, Sudarso and Anjar, 2011). Resistensi antibiotik merupakan keadaan dimana pertumbuhan bakteri tidak lagi dapat terhambat dengan pemberian antibiotika pada dosis normal atau kadar hambat minimalnya (Tripathi, 2003). Bakteri yang resistensi terhadap antibiotik akan mampu bertahan hidup dan berkembang biak yang kemudian akan menimbulkan lebih banyak bahaya bagi tubuh (Nugroho, 2011). 
Namun, sebagaian besar penulis resep masih cenderung meresepkan antibiotik untuk diagnosis-diagnosis yang sebetulnya tidak diperlukan antibiotik dalam terapinya seperti diare non spesifik dan ISPA non Pneumonia. Peran apoteker dalam hal ini yaitu mengkomunikasikan kepada dokter mengenai peresepan antibiotik dan melakukan konfirmasi kepada dokter apabila ditemukan resep berisi antibiotik terutama untuk pasien diare non spesifik dan ISPA non Pneumonia.

Realisasi dan capaian kinerja apoteker di Puskesmas Kota Banjarmasin pada indikator persentase penggunaan antibiotik pada diare non spesifik adalah seperti yang tercantum pada tabel 9 .

Tabel 9. Persentase Penggunaan Antibiotik Pada Diare Non Spesifik

\begin{tabular}{ccccc}
\hline $\begin{array}{c}\text { Target } \\
\text { Skor }\end{array}$ & Puskesmas & $\begin{array}{c}\text { Realisasi } \\
(\mathbf{1 0 0 \% )}\end{array}$ & $\begin{array}{c}\text { Capaian } \\
\mathbf{( \% )}\end{array}$ & $\begin{array}{c}\text { Kategori } \\
\text { Capaian }\end{array}$ \\
\hline $\mathbf{8} \%$ & $\begin{array}{c}\text { Alalak } \\
\text { Tengah }\end{array}$ & 27 & 79,35 & Sangat Tinggi \\
\cline { 2 - 5 } & $\begin{array}{c}\text { Banjarmasin } \\
\text { Indah }\end{array}$ & 83 & 18,48 & Sangat Tinggi \\
\cline { 2 - 5 } & $\begin{array}{c}\text { Cempaka } \\
\text { Putih }\end{array}$ & 0 & 100 & Sangat Tinggi \\
& $\begin{array}{c}\text { Pekauman } \\
\end{array}$ & 12 & 95,65 & Sangat Tinggi \\
\hline Teluk Dalam & 23 & 83,70 & Sangat Tinggi \\
\hline Rata-rata \pm SD & 29 & 75,43 & Sangat Tinggi \\
\hline
\end{tabular}

Realisasi dan capaian kinerja apoteker di Puskesmas Kota Banjarmasin pada indikator persentase penggunaan antibiotik pada ISPA non Pneumonia adalah seperti yang tercantum pada tabel 10 .

Tabel 10. Persentase Penggunaan Antibiotik Pada ISPA non Pneumonia

\begin{tabular}{|c|c|c|c|c|}
\hline $\begin{array}{l}\text { Target } \\
\text { Skor }\end{array}$ & Puskesmas & $\begin{array}{c}\text { Realisasi } \\
(100 \%)\end{array}$ & $\begin{array}{c}\text { Capaian } \\
(\%)\end{array}$ & $\begin{array}{l}\text { Kategori } \\
\text { Capaian }\end{array}$ \\
\hline \multirow[t]{6}{*}{$\leq \mathbf{2 0} \%$} & $\begin{array}{l}\text { Alalak } \\
\text { Tengah }\end{array}$ & 48 & 65 & Rendah \\
\hline & $\begin{array}{l}\text { Banjarmasin } \\
\text { Indah }\end{array}$ & 91 & 1,80 & Sangat Rendah \\
\hline & $\begin{array}{c}\text { Cempaka } \\
\text { Putih }\end{array}$ & 0 & 100 & Sangat Tinggi \\
\hline & Pekauman & 8 & 100 & Sangat Tinggi \\
\hline & Teluk Dalam & 43 & 71,25 & Sedang \\
\hline & Rata-rata \pm SD & 38 & 67,61 & Sedang \\
\hline
\end{tabular}

Hasil penelitian ini menunjukkan bahwa kinerja apoteker dalam indikator persentase penggunaan antibiotik pada diare non spesifik termasuk dalam kategori tinggi dengan capaian kinerja $75,44 \%$ dan persentase penggunaan antibiotik pada ISPA non Pneumonia termasuk dalam kategori sedang dengan capaian sebesar $67,61 \%$, meskipun pada realisasinya kedua indikator tersebut belum memenuhi target yang telah ditetapkan dimana persentase penggunaan antibiotik pada diare non spesifik adalah sebesar $29 \%$ dan persentase penggunaan antibiotik pada ISPA non pneumonia sebesar 38\%. Penggunaan antibiotik yang berlebihan di puskesmas dapat diatasi dengan pembuatan panduan terapi yang merupakan salah satu perangkat untuk tercapainya penggunaan obat rasional. Penelitian yang dilakukan oleh Kardela dkk. (2014) menunjukkan penggunaan persentase antibiotik di Puskesmas Jakarta Selatan yang menunjukkan hasil yang hampir sama dengan persentase penggunaan antibiotik di Puskesmas Kota Banjarmasin yaitu mencapai $56 \%$ pada puskesmas perawatan dan $32,67 \%$ pada puskesmas non perawatan (Kardela, Andrajati and Supardi, 2014). Pelaporan Dinas Kesehatan Provinsi terkait data peresepan nasional pada tahun 2011 sampai 2015 menunjukkan bahwa persentase penggunaan antibiotik pada diare nonspesifik mencapai $>40 \%$ dan pada ISPA non spesifik mencapai $>35 \%$ (Infarkes, 2016). Hasil penelitian ini menunjukkan terdapat peningkatan capaian terhadap penggunaan antibiotik baik pada diare non spesifik maupun ISPA non pneumonia dibandingkan dengan capaian nasional pada tahun 2011- 2015. Penulis resep sebaiknya lebih berfokus dalam pemberian oralit yang lebih dianjurkan pada pasien dengan diare non spesifik untuk mencegah terjadinya dehidrasi dibandingkan dengan pemberian antibiotika karena terjadinya dehidrasi dapat membahayakan jiwa terutama pada anak yang mengalami diare (Kemenkes RI, 2011). Pada kasus ISPA, sebagian besar kasus ISPA bukan disebabkan oleh bakteri tetapi disebabkan oleh virus yang tidak memerlukan antibiotika dalam terapinya. Pemberian antibiotik pada ISPA non pneumonia termasuk kedalam peresepan yang berlebihan yaitu pemberian obat yang sebenarnya tidak diperlukan untuk penyakit yang bersangkutan (Kemenkes RI, 2011). Peresepan antibiotik yang tidak perlu dan berlebihan dapat disebabkan karena adanya persepsi pasien bahwa pengobatan dengan menggunakan antibiotik akan lebih efektif dibandingkan pengobatan tanpa antibiotik sehingga pasien yang percaya dengan efektifitas antibiotik akan diresepkan antibiotik lebih sering oleh dokter, oleh karena itu pasien perlu diberikan informasi dan pemahaman lebih lanjut mengenai antibiotik (Chang et al., 2019). Peresepan antibiotik yang berlebihan dan tidak rasional dapat menjadi ancaman yang serius karena dapat 
mempercepat terjadinya resitensi antibiotik dan memperlambat penemuan dan pengembagan agen antibakteri yang baru (Mamo and Alemu, 2020). Salah satu upaya yang dapat dilakukan untuk mengatasi dan mengubah kebiasaan terkait dengan penggunaan antibiotik yang tidak rasional dan berlebihan ini adalah dengan adanya komunikasi yang efektif antara apoteker dan dokter serta tenaga kesehatan lainya terkait dengan persepan antibiotik yang berlebihan.

\section{d. Persentase Penggunaan Injeksi Pada Myalgia}

Myalgia merupakan nyeri otot yang yang disebabkan kerja, beban dan penguluran otot yang berlebihan serta cedera otot yang disebabkan aktivitas sehari-hari. Tatalaksana terapi mylagia pada fasilitas kesehatan primer adalah dengan menggunakan obat antiinflamasi steroid atau obat antiinflamasi nonsteroid oral, sehingga penggunaan injeksi bukan merupakan hal yang tepat untuk diberikan pada pasien myalgia (Kemenkes RI, 2014). Selain itu penggunaa injeksi lebih ditujukan untuk pelayanan kesehatan rawat inap di rumah sakit atau tempat praktik dokter yang dilakukan oleh dokter atau perawat yang kompeten. Puskesmas di Kota Banjarmasin merupakan puskesmas rawat jalan sehingga seharusnya tidak ada sediaan injeksi yang digunakan selain di ruang poligigi. Kinerja apoteker dalam indikator persentase penggunaan injeksi pada myalgia di Puskesmas Kota Banjarmasin ditunjukan pada tabel 11.

\begin{tabular}{ccccc} 
Tabel 11. & $\begin{array}{c}\text { Persentase } \\
\text { Myalgia }\end{array}$ & Penggunaan & Injeksi Pada \\
\hline $\begin{array}{c}\text { Target } \\
\text { Skor }\end{array}$ & Puskesmas & $\begin{array}{c}\text { Realisasi } \\
\mathbf{( 1 0 0 \% )}\end{array}$ & $\begin{array}{c}\text { Capaian } \\
\mathbf{( \% )}\end{array}$ & $\begin{array}{c}\text { Kategori } \\
\text { Capaian }\end{array}$ \\
\hline $\mathbf{1 \%} \%$ & Alalak Tengah & 0 & 100 & Sangat Tinggi \\
\cline { 2 - 5 } & $\begin{array}{c}\text { Banjarmasin } \\
\text { Indah }\end{array}$ & 0 & 100 & Sangat Tinggi \\
\cline { 2 - 5 } & $\begin{array}{c}\text { Cempaka Putih } \\
\end{array}$ & 0 & 100 & Sangat Tinggi \\
\cline { 2 - 5 } & Pekauman & 0 & 100 & Sangat Tinggi \\
\hline Teluk Dalam & 0 & 100 & Sangat Tinggi \\
\hline & Rata-rata $\pm S D$ & 0 & 100 & Sangat Tinggi \\
\hline
\end{tabular}

Penelitian ini menunjukkan kinerja apoteker pada indikator ini termasuk dalam kategori sangat tinggi dengan capaian $100 \%$. Penelitian ini menunjukkan bahwa injeksi pada myalgia sudah tidak pernah lagi digunakan di Puskesmas Kota Banjarmasin. Penelitian yang dilakukan oleh Dwiprahasto (2006) menunjukkan persentase pemberian injeksi pada kasus myalgia sebelum intervensi diberikan adalah sebesar $69,11 \%$ dan menurun menjadi $31,89 \%$ setelah dilakukan intervensi meskipun hasil tersebut belum sesuai dengan standar yang telah ditetapkan (Dwiprahasto, 2006). Kebiasaan memberikan obat dalam bentuk injeksi dapat menyebabkan kerugian baik dari segi klinis maupun finansial. Kerugian klinis yang mungkin akan terjadi adalah meningkatnya resiko terjadinya syok anafilaksis pada pasien dan secara finansial akan merugikan pasien maupun puskesmas karena harga sediaan injeksi yang cenderung lebih mahal dibandingkan dengan sediaan oral (Kemenkes RI, 2011).

Penjelasan diatas menggambarkan bahwa kinerja apoteker dalam melakukan pelayanan farmasi klinis sudah baik, tidak ada indikator yang berada pada kategori rendah dan sangat rendah. Namun terdapat indikator dengan kategori capaian kinerja sedang yang perlu ditingkatkan kembali capaiannya. Indikator yang berada pada ketegori sedang tersebut adalah persentase penggunaan antibiotik pada ISPA non penumonia dan konseling. Konseling harus tetap dilakukan dengan persetujuan pasien meskipun di Puskesmas Kota Banjarmasin tidak terdapat ruang konseling apoteker dan juga perlu dilakukannya dokumentasi konseling. Kegiatan dokumentasi perlu dilakukan untuk evaluasi kegiatan dalan upaya peningkatan mutu pelayanan. Dokumentasi kegiatan konseling sendiri perlu dilakukan untuk mendapatkan profil pasien, mengetahui riwayat penyakit pasien, memantau kepatuhan pasien dalam berobat, mengevaluasi pemahaman pasien tentang pengobatan, menyediakan data apabila terjadi tuntutan pada kesalahan penggunaan obat, menyediakan data untuk evaluasi kegiatan kefarmasian serta menyediakan data untuk evaluasi terapi (Depkes RI, 2006).

\section{Batasan Penelitian}

Penelitian ini dapat memberikan manfaat untuk mengetahui pencapaian apoteker terhadap tugas dan kewajibannya dalam melaksanakan pelayanan farmasi klinik di Puskesmas sesuai dengan target dan standar yang telah ditetapkan sehingga dapat digunakan sebagai masukan untuk terus meningkatkan kinerja apoteker di Puskesmas agar dapat memberikan pelayanan kefarmasian yang sesuai dengan standar, selain itu hasil dari analisis kinerja apoteker juga dapat digunakan sebagai dasar dalam pemberian insentif berbasis kinerja bagi apoteker di Puskesmas. Penelitian ini juga memiliki beberapa keterbatasan yaitu belum semua aspek farmasi klinik yang terdapat pada PMK 74 tahun 2016 dianalisis; pengisian daftar tilik masih dilakukan atas prespektif peneliti dan hanya dilakukan 
selama satu minggu pada setiap puskesmas. Selain itu wawancara hanya dilakukan kepada satu informan yaitu Apoteker Kepala Bidang Pelayanan dan Sumber Daya Kesehatan yang membawahi seksi Kefarmasian Dinas Kesehatan Kota Banjarmasin.

\section{KESIMPULAN}

Kinerja apoteker dalam pelayanan farmasi klinik di Puskesmas pada era Jaminan Kesehatan Nasional berada pada kategori sangat tinggi pada aspek penggunaan obat generik, rata-rata item obat dalam resep dan penggunaan injeksi pada myalgia. Kategori kinerja yang tinggi ditunjukkan pada aspek pengkajian resep, rata-rata item obat dalam resep dan penggunaan antibiotik pada diare non spesifik. Kategori kinerja sedang ditunjukkan melalui aspek konseling pasien dan penggunaan antibiotik pada ISPA non pneumonia.

\section{DAFTAR PUSTAKA}

Chaira, S., Zaini, E. and Augia, T. (2016). Evaluasi Pengelolaan Obat pada Puskesmas di Kota Pariaman, Jurnal Sains Farmasi \& Klinis, 3, pp. 35-41.

Chang, Y. et al. (2019). Clinical pattern of antibiotic overuse and misuse in primary healthcare hospitals in the southwest of China, Plos ONE.

Coombes, I. et al. (2010). Improvement in Pharmacist's Performance Facilitated by an Adapted Competency-Based General Level Framework, Journal Of Pharmacy Practice and Research, 40(2), pp. 111-118.

Depkes RI (2006). Pedoman Supervisi dan Evaluasi Obat Publik dan Perbekalan Kesehatan. Jakarta: Departemen Kesehatan Republik Indonesia.

Duerden, M. and Rupert, P. (2014). Polypharmacy what is it and how common is it? Polypharmacy.

Dwiprahasto, I. (2006). Peningkatan Mutu Penggunaan Obat Di Puskesmas Melalui Pelatihan Berjenjang Pada Dokter Dan Perawat, Jurnal Manajemen Pelayanan Kesehatan, 9.

Ejeta, F. et al. (2021). Medication Counseling Practices in Medicine Retail Outlets Found in Bench Sheko Zone, Southern Nations, Nationalities, and Peoples' Region, South West Ethiopia, Pragmatic and Observational Research, 12, pp. 105-117.
Handayani, R, S. et al. (2009). Ketersediaan dan Peresepan Obat Generik dan Obat Esensial di Fasilitas Pelayanan Kefarmasian di 10 Kabupaten/Kota di Indonesia, Buletin Penelitian Sistem Kesehatan, 13, pp. 54-60.

Hartanto, F.. (2017). Analisis Ketaatan Pelaksanaan standar prosedur operasional pelayanan kefarmasian: studi pada puskesmas terakreditasi di kabupaten sleman. Universitas Gadjah Mada Yogyakarta.

Holmes, H. (2012). Olypharmacy, An Issue Of Clinics In Geriatric Medicine. Elsivier Health Sciences, Elsivier Health Sciences, pp. 440-445.

Infarkes, (2016). Tantangan Dalam Pelayanan Kefarmasian Antibiotik Bijak Demi Masa Depan. Jakarta: Informasi Kesehatan dan Alat Kesehatan Dikrektorat Jendral Kefarmasian Dan Alat Kesehatan.

Kardela, W., Andrajati, R. and Supardi, S. (2014). Perbandingan Penggunaan Obat Rasional Berdasarkan Indikator WHO di Puskesmas Kecamatan antara Kota Depok dan Jakarta Selatan, Jurnal Kefarmasian Indonesia, 4, pp. 91-102.

Kemenkes RI. (2010). Peraturan Menteri Kesehatan Republik Indonesia, Nomor HK.02.02/ MENKES/068/I/2010, tentang Kewajiban Menggunakan Obat Generik di Fasilitas Pelayanan Kesehatan Pemerintah. Jakarta: Kementerian Kesehatan Republik Indonesia.

Kemenkes RI. (2011). Modul Penggunaan Obat Rasional. Jakarta: Kementerian Kesehatan Republik Indonesia.

Kemenkes RI. (2014). Peraturan Menteri Kesehatan Republik Indonesia Nomor 5 Tahun 2014 Tentang Panduan Praktik Klinis Bagi Dokter di Fasilitas Pelayanan Kesehatan Primer. Jakarta: Kementerian Kesehatan Republik Indonesia.

Kemenkes RI. (2015). Rencana Aksi Kegiatan Tahun 2015-2019: Direktorat Bina Pelayanan Kefarmasian. Jakarta: Direktorat Bina Pelayanan Kefarmasian.

Kemenkes RI. (2016). Peraturan Menteri Kesehatan Republik Indonesia Nomor 74 Tahun 2016 Tentang Standar Pelayanan Kefarmasian di Puskesmas. Jakarta: Kementerian Kesehatan Republik Indonesia. 
Kim, H. . et al. (2014). Prevalence and Predictors Of Polypharmacy among Korean Elderly, Plos ONE, 9, pp. 1-7.

Latifah, E., Pribadi, P. and Yuliastuti, F. (2016). Penerapan Standar Pelayanan Kefarmasian Di Apotek Kota Magelang, Jurnal Farmasi Sains dan Praktis, 2, pp. 11-17.

Mamo, D. B. and Alemu, B. K. (2020). World, Rational Drug-Use Evaluation Based on In, Health Organization Core Drug-Use Indicators a Tertiary Referral Hospital, Northeast Ethiopia: A Study, Cross-Sectional, Drug, Healthcare and Patient Safety, 12, pp. 15-21.

Nugroho, A. (2011). Farmakologi : Obat-obat Penting Dalam Pembelajaran Ilmu Farmasi dan Dunia Kesehatan. Jakarta: Pustaka Belajar.

Palaian, S., Prabhu, M. and Shankar, P. (2006). Patient Counseling By Pharmacist -A Focus On Chronic Illness, Pakistan Journal of Pharmaceutical Sciences, 19, pp. 65-72.

Pemkot Banjarmasin. (2005). Rencana Pembangunan Jangka Panjang (RPJP) KOTA Banjarmasin Tahun 2006 - 2025. Banjarmasin: Pemerintah Kota Banjarmasin.

Quick, J. et al. (2012). Managing Drug Supply, The Selection, Procurement, Distribution and Use of Pharmaceutical. 3rd edn. USA: Kumarin Press.

Rajiah, K. et al. (2016). Community Pharmacists' Perception on Patient Counseling and Continuing Pharmacy Education Program in East Malaysia, Malaysian Journal of Public Health Medicine, 16, pp. 15-22.

Rifa'i, M., Sudarso and Anjar, M. (2011). Evaluasi Penggunaan Antibiotik Terhadap Pasien Anak Penderita Demam Tifoid Di Rumah Sakit Wijayakusuma Purwokerto Tahun 2009, Pharmacy, 08, pp. 13-24.

Sanii, Y. et al. (2016). Role of pharmacist counseling in pharmacotherapy quality improvement, Journal Of Research in Pharmacy Practice, 5, pp. 132-137.

Satibi et al. (2018). Analisis Kinerja Apoteker dan Faktor yang Mempengaruhi Pada Era Jaminan Kesehatan Nasional di Puskesmas, Jurnal Manajemen dan Pelayanan Farmasi, 8 (1).
Tanner, A., Ranti, L. and Lolo, W. (2015). Evaluasi Pelaksanaan Pelayanan Resep Obat Generik Pada Pasien BPJS Rawat Jalan Di RSUP. Prof. Dr. R.D. Kandou Manado Periode Januari-Juni 2014, Jurnal Ilmiah Farmasi, 4, pp. 58-64.

Tripathi, K. (2003). Essential of Medical Pharmacology', Jaypee Brothers Medical Publishers, 5, pp. 552-589.

Wibowo, M. I. N. . et al. (2016). Tingkat Kepuasan Pasien Terhadap Kinerja Apoteker Puskesmas Di Tiga Kabupaten: Purbalingga, Banjarnegara, Cilacap Tahun 2015, Journal Pharmacy, 14, pp. 46-70.

Yuniar, Y. and Handayani, R. (2007). Indikator Peresepan Obat Pada Enam Apotek Dl Kota Bandung, Surabaya Dan Makassar', Buletin Penelitian Sistem Kesehatan, 10, pp. 25-30. 